\title{
Indonesian Vocational High School Readiness Toward Society 5.0
}

Hilmawan Wibawanto ${ }^{*}$, Roemintoyo ${ }^{2}$, Triana Rejekiningsih ${ }^{3}$

${ }^{1,2}$ Sebelas Maret University, Indonesia

\begin{tabular}{|c|c|}
\hline A R T I C L E I N F O & A B S T R A C T \\
\hline $\begin{array}{l}\text { Article history: } \\
\text { Received } 18 \text { December } \\
2020 \\
\text { Received in revised } \\
\text { Form } 06 \text { January } 2021 \\
\text { Accepted } 1 \text { February } 2021 \\
\text { Available online } 09 \\
\text { February } 2021\end{array}$ & $\begin{array}{l}\text { Vocational high school comprehensively relates technology studies, the } \\
\text { development of acquisition of practical skills, attitudes, and life skills. In this } \\
\text { context, teachers play important role in forming and producing competent } \\
\text { graduates' need toward Society } 5.0 \text {. This study aims to analyze teachers' } \\
\text { perceptions about vocational high school readiness toward Society } 5.0 \text {. This study } \\
\text { used a descriptive quantitative with survey method. The respondents were } \\
\text { vocational high school teachers that have been selected using a random sampling } \\
\text { method. The result indicated teachers' understanding of Society } 5.0 \text { is low. The }\end{array}$ \\
\hline $\begin{array}{l}\text { Keywords: } \\
\text { school readiness, } \\
\text { society } 5.0\end{array}$ & $\begin{array}{l}\text { school's readiness to facilitate learning also quite low. The assessments still } \\
\text { generalized requirements for student achievement. On the other hand, teachers } \\
\text { still have the motivation to learn to use technology. The majority of teachers often } \\
\text { attend training to improve instructional media skills. Based on these results, } \\
\text { school preparation needs to be improved in terms of teacher competence and } \\
\text { learning support facilities for Society } 5.0 \text {. }\end{array}$ \\
\hline
\end{tabular}
learning support facilities for Society 5.0.

\section{Introduction}

Society 5.0 is a concept of society that was introduced by the Japanese government (Skobelev \& Borovik, 2017). The concept of this society is using human-centered technology (Shiroishi et al., 2018). Society 5.0 uses super technology with Internet of Things (IoT), big data (BD), and artificial intelligence (AI) (Frey \& Osborne, 2017). The existence of new technology always impacts on the needs of experts in the field of systems engineering. A new training program must also be implemented to increase human resources in this field (Ministry of Education, Culture, Sport, and Technology, 2019).

Vocational high school comprehensively relates technology studies, the development of acquisition of practical skills, attitudes, and life skills. In this context, teachers play important role in forming and producing competent graduates' need toward Society 5.0 (Mulyadi, 2019). Teachers must be able to make students achieve competencies that are in accordance with industry needs. In this era, teachers are required to master expertise, ability to adapt to new technologies and global challenges.

In Indonesia, technology in the education system developed rapidly during the Covid-19 pandemic starting from February 2020. This assumption is based on the number of schools in Indonesia that are starting to use technology for distance learning activities. Efforts to implement learning are still underway to produce vocational school graduates who have the knowledge, skills and attitudes as skilled workers (Mulyanti et al., 2020). Online learning or e-learning is a solution to continuously transfer knowledge to students during the Covid-19 pandemic. Online learning is an alternative for educators and students in different places (Verawardina et al., 2020).

Schools as components of education must be able to facilitate virtual learning for students and teachers so that learning objectives are achieved. Innovation and variations in the use of learning methods can be a solution to meet the challenges of education. Some subjects may require slight movement and physical contact (Cahapay, 2020), such as subjects in vocational schools. For this reason, it is necessary to assess the ability of schools to facilitate learning and teacher readiness (Obana, 2020).

Previous research has revealed the readiness of some schools with different perspective. First research from Syarif, et al, proved that elementary schools have implemented one of society 5.0 competencies, such as problem solving to students effectively, using three products, namely student books, teacher books, and local instructional theory (Syarif et al., 2019). Machfiroh, et al, also proved that education in Indonesia education in Indonesia is ready to face society 5.0, this is based on the use of the internet and social media in Indonesian society. The youth believed that education can take advantage of social media 
such as Facebook and Instagram to facilitate distance learning (Machfiroh et al., 2020). In the other hand, Purnamasari, et al, proved that some students still unready for facing the new eras, because their preparedness and impact for their profession are more difficult to learn the process (Purnamasari et al., 2019). From the previous research, we can say that schools in Indonesia still have the constraints of a lack of preparation, although in some perspectives they are confident about the readiness to a 5.0 society. Therefore, there is a need for further research on the readiness of schools to face society 5.0, especially in vocational high schools which are more related to development of technology.

Studies about school readiness in realizing virtual learning show that schools need to plan solutions by assessing the ability of schools to prepare electricity supply, internet connectivity, and teacher competence (Cahapay, 2020). Then, Mulyadi argues that increasing the competence of vocational high school teachers in the era of high technology must begin to be directed at new concepts and paradigms (Mulyadi, 2019). Furthermore, Wagiran, et. al. also argues that future vocational high school teachers need to have competencies that are relevant to hard skill aspects, such as pedagogic knowledge (instructional), content knowledge, and educational technology (Wagiran et al., 2019). So, in this study it is necessary to explore how the readiness of vocational high schools and teachers' competencies.

The objective of this study is to find out the readiness of vocational high schools in realizing Society 5.0. It is necessary to conduct a study to investigate the understanding of teachers related to Society 5.0, online learning activities, and teacher competencies in using technology for learning. Assessment is based on an online learning process during the COVID-19 pandemic. The results of the analysis are an assessment for the readiness of vocational high schools in Indonesia. It can provide a meaningful learning experience for students without being burdened with demands to complete all curriculum targets for grade promotion or graduation.

\section{Methods}

This research used quantitative methods through descriptive approach. Data collection techniques in this quantitative study used a questionnaire and literature review. The questionnaire aims to find the problem and conditions to vocational readiness toward society 5.0 by asking various questions. The questions ask about perceptual data about school readiness from the aspect of teachers' understanding of society 5.0, school facilities' readiness, learning activities and teacher competence in applying technology. The respondents are vocational high school teachers in Surakarta, especially the building engineering teachers, were selected by random sampling technique to answer questions on the questionnaire. Before questionnaires are distributed, the questions passed the validity stage by expert's judgement. Because of pandemic Covid-19, the questionnaires are distributed with google form. The quantitative data from questionnaires were analysed using descriptive quantitative techniques that using histogram or charts. The literature review aims to obtain relevant data about what schools need to prepare for society 5.0. This technique is used to compare the data obtained with previous research data or other relevant studies. Then, all data collected from questionnaires and literature reviews are analysed and discussed to get suggestions and solutions for school toward society 5.0

\section{Result and Discussion}

\section{Results}

This research was conducted with respondents from building engineering teachers of vocational high schools in Surakarta. The composition of respondents consisted of $27,3 \%$ with less than 5 years teaching experience, $9,1 \%$ with 5-10 years teaching experience, $27,3 \%$ with $10-20$ years teaching experience, and $36,4 \%$ with over 20 years teaching experience. Data in teaching experience shows that teachers have had a lot of experience in the learning process with various learning models and curriculum content. The results of the questionnaire obtained from the respondents, such as: teachers' understanding of the society 5.0 technologies (Figure 1), school's facilities readiness (Figure 2 and 3), online learning activities (Figure 4), and teachers' competencies (Figure 5 and 6). 


\section{TEACHERS' UNDERSTANDING OF THE SOCIETY 5.0 TECHNOLOGIES}

20

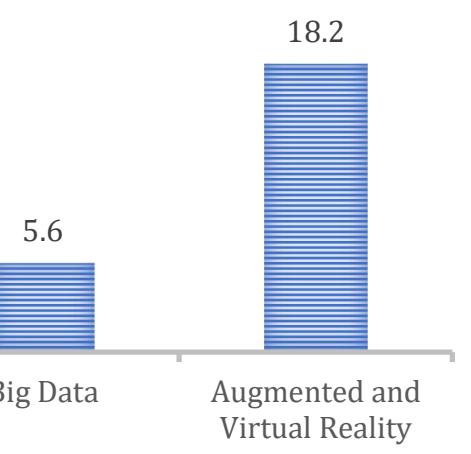

Figure 1. Research Result of Teacher Understanding about The Society 5.0 Technologies

Figure 1 displays the percentage of teacher knowledge about Society 5.0. The survey results state that only 9,1\% of teachers know about Artificial Intelligence (AI), 3,1\% of teachers know about the Internet of Thins (IoT), 5,6\% of teachers know about Big Data (BD), and 18,2\% The teachers know about Augmented Reality (AR) and Virtual Reality (VR). All results state that the teacher's understanding of Society 5.0 is less than $20 \%$.

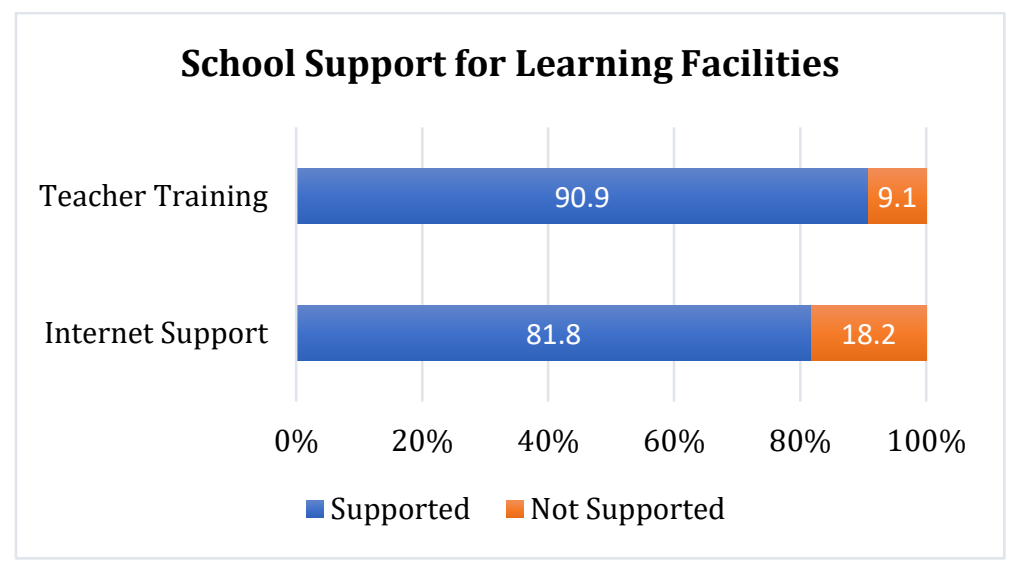

Figure 2. School's Support for Learning Facilities

Figure 2 indicates school's support for learning facilities during COVID-19 pandemic. Based on this percentage, $90,9 \%$ of respondents claimed that schools facilitate teachers to attend learning technology training. In addition, 81,8\% of respondents claimed that schools also support internet for teachers and students. Based on the results of both, vocational high schools have a high effort in facilitating their teachers and students.

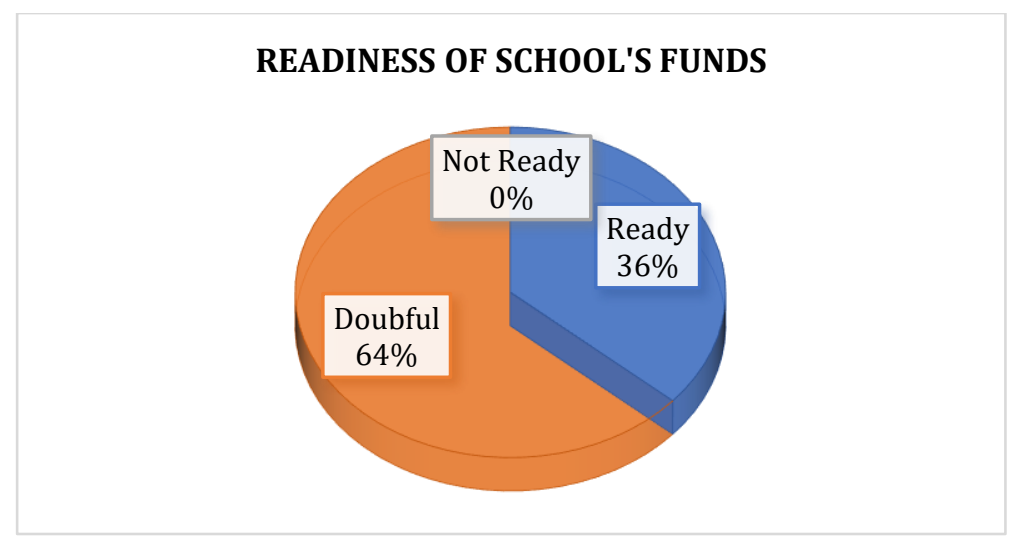

Figure 3. Readiness of School's Funds. 
From figure 3 , the data indicated that $36 \%$ of respondents have perception that schools have the readiness of funds to realize Society 5.0. The remaining $64 \%$ are still unsure of the readiness of funds owned by schools. Beside the good result about school's support for facilitating learning, teachers are still unsure about school's funds.

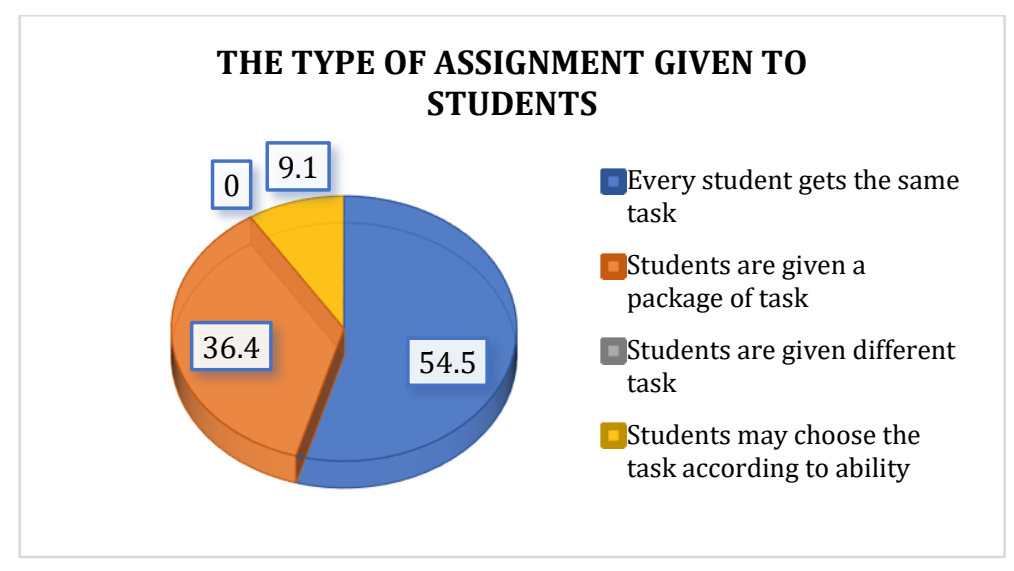

Figure 4. The Type of Assignment Given to Students.

From the figure 4 , we can see that $54 \%$ of respondents claimed that every student gets the same task. It's means that all students' assessments still generalized. 36,4\% of respondents claimed that students are given a package of task. For package of task and different task model indicates that students randomly get questions that may not be according to their competence. Only 9,1\% of respondents claimed that student may choose the task according to their ability.

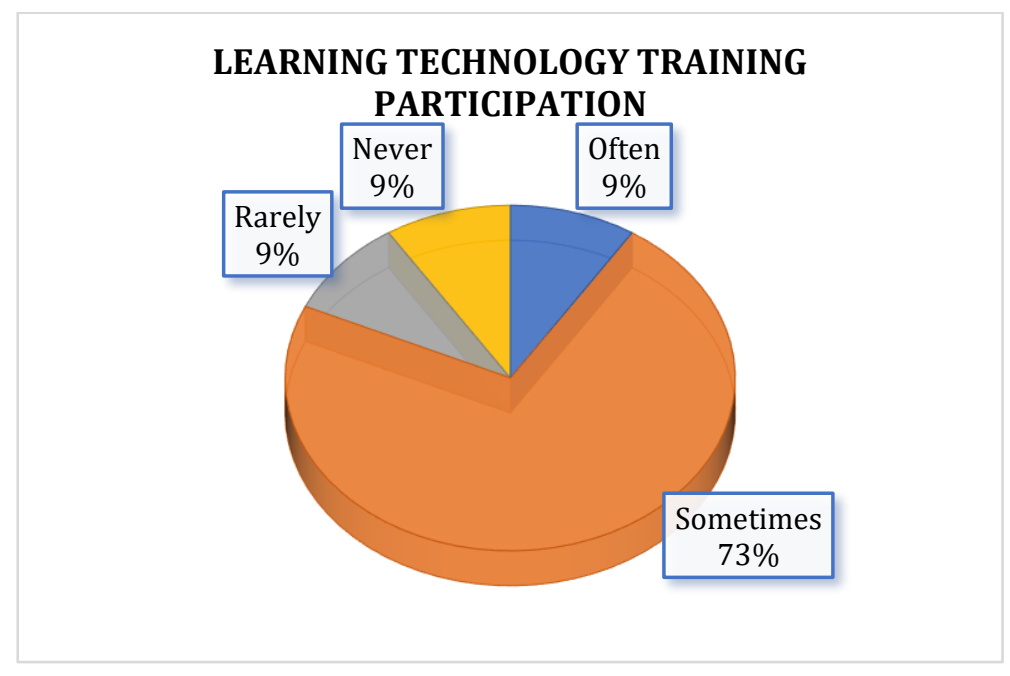

Figure 5. Learning Technology Training Participation.

Based on Figure 5, the majority of teachers attend training in order to improve their competence in learning technology. From this data, as many as $9 \%$ of teachers often attend training, $73 \%$ of teachers sometimes attend training, $9 \%$ of teachers rarely attend training, and $9 \%$ have never attended training. This teacher's efforts should be appreciated because they still have the motivation to learn technology as a learning aid. 


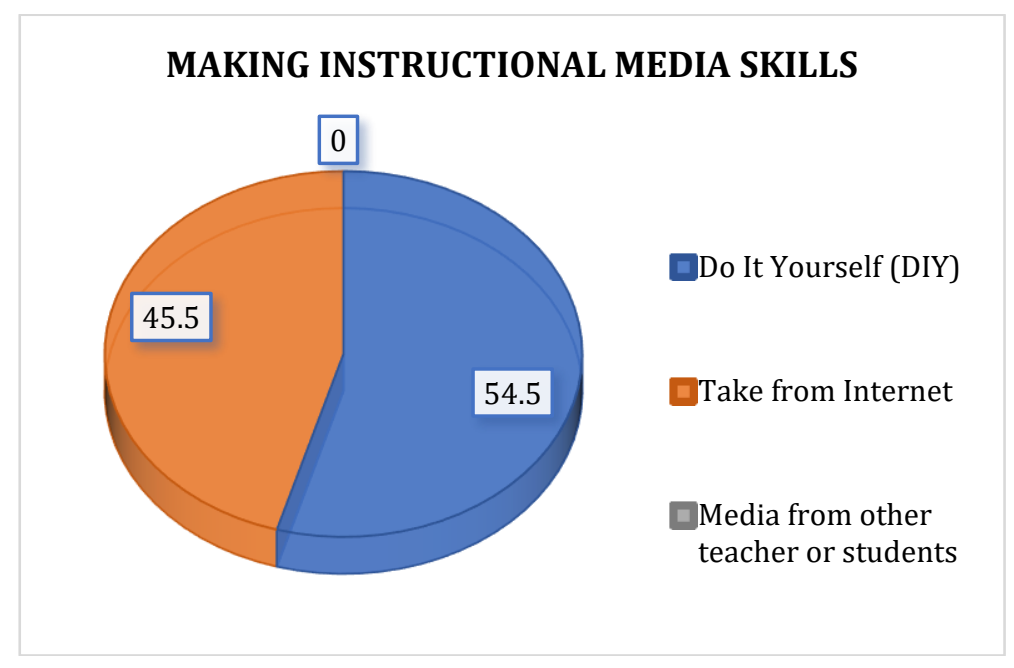

Figure 6. Making Instructional Media Skills.

Figure 6 indicated that the majority of teachers $(54,5 \%)$ made their own media, and the other teachers $(45,5 \%)$ take the media from internet. The teacher that made their own media must continue to develop themselves in making varied media. So, students are excited and interest in learning (Basilaia \& Kvavadze, 2020). On the other hand, teachers who have not been able to create media can follow in the footsteps of other teacher peers in training to improve their competence.

\section{Discussion}

Vocational teachers need a comprehensive understanding and competence of the elements of the industrial revolution 4.0. These elements include gadgets, IoT, artificial intelligence, big data, augmented and virtual reality, and other elements (Mulyadi, 2019). Society 5.0 introduced the main technologies used in that era, including artificial intelligence, IoT, big data, augmented reality and virtual reality. Based on these results in figure 1, the highest percentage is in understanding augmented reality (AR) and virtual reality (VR). This is because AR and VR products are starting to be found for game products on smartphones and game consoles. Meanwhile, not many have recognized artificial intelligence (AI), Internet of Things (IoT), and Big Data (BD), because this is something new in the world of education. In the era of Society 5.0, the application of these technologies, especially AI, occupies a sizable portion, because real-time execution between virtual and real space is carried out autonomously (Mulyadi, 2019). Currently, teachers need to prepare their competencies to realize Society 5.0 with seminars and training or workshop.

This research also investigates the readiness of schools and teachers in realizing Society 5.0. The school readiness is efforts of the schools and its' components to present or facilitating learning activities (Cahill et al., 2020). There are three aspects assessed, such as school readiness in facilitating teachers and students; online learning activities; and teacher competencies in utilizing technology. Assessment is based on an online learning process during the COVID-19 pandemic.

\section{School Readiness in Facilitating Teacher and Students}

Schools must be prepared to facilitate teachers and students to improve the quality of educational. Efforts to improve the quality of learning can be by providing support in the form of training for teachers and support for technology-based learning facilities. The results of the analysis of school efforts to facilitate teachers and students during COVID-19 can be seen in Figure 2. Based on the survey results, schools generally provide supports such as teacher training and free internet quotas. Teacher training is important because vocational high school and public high school teachers are different. Teachers in vocational secondary schools need to have stronger pedagogical competence (Wagiran et al., 2019). Education with high technology requires teachers to master pedagogical competence by mastering instructional media technology (Halimah \& Syaddad, 2020). Internet support for teachers and students is also an important thing to prepared by schools. The low availability of internet access is a major factor in the lack of motivation for students to study independently and to find sources of learning information on their own (Rahardjo et al., 2016). The willingness of the internet for learning can make teachers and students more freely explore learning materials. This also affects students who have economic constraints that find it difficult to buy internet quotas. 
Teachers' perception about school funds (Figure 3), especially for public schools, must be related to assistance from the government. Schools must be provided with materials and financial resources to facilitating the development of their staffs and teachers' digital competencies (Huber \& Helm, 2020). Local governments need to take on a more active role in aiding the schools than initiatives by the central government. In addition to using existing School Operational Assistance (Bantuan Operasional Sekolah/BOS) funds, local education authorities need to provide schools with further financial support and technical assistance, such as access to recording studios and equipment, to accelerate their adoption of distance learning. Such assistance should not neglect private community schools. This assistance can be a determinant of the readiness of funds to facilitate schools to realize Society 5.0.

\section{Online Learning Activities}

One of the tendencies associated with society 5.0 in the field of education is to provide learning according to student choices (Fisk, 2017). In this context, students have the right to determine how they learn so that they have different skills according to the field of interest. The results of the online learning activity survey can be seen in Figure 4. These problems are usually the lack of teachers' digital media and skills (Onyema et al., 2020). The teacher must be more creative and innovative in giving assignments to students. One of the efforts is to create new innovations in learning methods (Cahapay, 2020). It is better if online learning is carried out collaboratively so that students can participate and improve collaboration skills, motivation, satisfaction, and attitudes towards the use of technology (Julia \& Antoli, 2018; Shonfeld \& Magen-nagar, 2017). Conceptually for better online learning environment, vocational school teachers must prepare a learning process that brings their students into the world of work in accordance with the challenges and needs of the times. There are many facts in the field that doubt the competence of teachers in the fields of study they teach and in other fields (Mulyadi, 2019).

Learning approaches and models must continue to be developed for teacher professionalism. In designing learning approaches and models, it is necessary to focus on the student-centered concept, so it can be meaningful learning and students can implement their learning experiences over along the way (Engerman et al., 2019; Engerman \& Otto, 2021). It is necessary to design learning that considered the learning competencies or outcomes, scope of the content, learning activities, learning assessment (Bennett et al., 2017). Much like the professional teacher design the instructional with subject needs. The competency indicators for professional vocational teachers need to be measured so that the achievement of student competencies can be determined according to industry needs. For the aims of $21^{\text {st }}$ educational century, it is concerned chiefly with a student's progression through curriculum at their own pace, depth, etc. So that students can continue their progress according to their competence. Learning like this usually uses projectbased learning.

\section{Teaching Competencies in Utilizing Technologies}

The use of internet for the Indonesian people, especially the Indonesian youth has increased by more than $90 \%$ over the last $2-3$ years. The strategy for realizing Society 5.0 is to use technology as an educational approach (Machfiroh et al., 2020). Teachers as a component of education must be able to balance technological abilities in the learning process so that they are not left behind by the younger generation and technological development over time.

The teacher becomes one of the main determinants of the success of the learning process. Teachers play important role in forming and producing competent graduates' need toward Society 5.0 (Mulyadi, 2019). In Society 5.0, educators must make students active and easy to understand learning material with technologies. This section discusses the enthusiasm of teachers in improving learning technology competencies and the skills in making instructional media.

The results (Figure 5 and 6) show that in general teachers have started to improve educational technology competencies in the form of learning media competencies. This competency is relevant to the hard skill aspects that future vocational teachers must have such as the pedagogic knowledge, content knowledge, and education technology (Koh, 2018; Wagiran et al., 2019). This competence is the key to the successful use of technology by the stages of lesson planning process (Chai et al., 2018). Teachers can develop classroom teaching by selecting and making suitable media with learning materials (Halimah \& Syaddad, 2020), and manage the informations to enhance their teaching practices (Spiteri et al., 2018). Sometimes, many students can face negative effect from new era, including school achievement. The better ways for our students, we must prepare the teacher and students with the skills that need to Society 5.0, so academics and experiences of the teachers and students are improve (Pears \& Kim, 2019).

In this digital era and $21^{\text {st }}$ century technology, teacher must have competencies include mastery of information technology, $21^{\text {st }}$ century pedagogy, content, knowledge or skills, evaluation and conceling (Rusdin, 2018) that listed on the TPACK domain. Technological and pedagogical skills can make learning 
more effective, so teacher must prepare and use the technology selectively and systematically (Jan, 2017). In the era of communication technology, TPACK skills is very important for teachers to communicate dan support their students in physical classroom and online classroom (Apau, 2017; Simaremare et al., 2020; Tondeur et al., 2016).

Another effort for schools to be ready to realize education in the era of society 5.0 is to implement technologies such as IoT, BD, and AI. Learning websites that exist at school can also be upgraded to become big data with artificial intelligence to improve student's literacy and vocational high school readiness toward society 5.0. The website can be designed for student databases, online learning tools, and online library, pictures and videos that can be accessed by teachers and students to enhance learning.

Professional teachers who have the task of producing graduates who are competent and able to work in industry must begin to think fundamentally based on the development of Society 5.0 technology because current work in various sectors will all refer to the Internet of Thing (IoT) system which requires giant data spaces in the form of cloud with unlimited capacity. Real space and virtual space will become a single unit for different learning. All real things that are difficult to do in a laboratory, workshop, class, or other place can be done virtually. Vocational teacher's understanding of the dynamics and development of technology becomes a need that requires alternative solutions as soon as possible so that technology education, especially in Vocational Schools, does not lag too far (Aoki et al., 2019)

\section{Conclusion}

The main effort in preparing education in the era of Society 5.0 is by increasing the competency of vocational teachers. The paradigm shift needs to be anticipated comprehensively, so that there are no cultural shocks, especially in the education process in vocational high schools. Teachers need to be systematically encouraged to think orientation, perspective, and enthusiasm in working to face the paradigm changes that occur. The government and schools also need to support and facilitate funds, infrastructure, and other programs for technological development to improve the quality of education. The fact is that realizing education in the Society 5.0 era is indeed a difficult thing if we look at the current condition of Indonesian education, but that does not mean it is impossible to make it happen. The education system needs to design learning solutions that promote high-level technology.

\section{References}

Aoki, Y., Nakamura, K., \& Yuminaka, Y. (2019). Science Education for Society 5 . 0. International Conference on Technology and Social Science, ICTSS 2019, 6-8. http://confejikei.org/ICTSS/2019/proceedings/materials/proc_files/Keynote/KL06_Prof.\%20Aoki/ICTSS2019_KL-06_Prof.Aoki.pdf.

Apau, S. K. (2017). Technological Pedagogical Content Knowledge Preparedness of Student- Teachers of the Department of Arts and Social Sciences Education of University of Cape Coast Technological Pedagogical Content Knowledge Preparedness of Student-Teachers of the Departmen. Journal of Education, 8(10), 167-181. http://hdl.handle.net/123456789/3228.

Basilaia, G., \& Kvavadze, D. (2020). Transition to Online Education in Schools during a SARS-CoV-2 Coronavirus (COVID-19) Pandemic in Georgia. Pedagogical Research, 5(4). https://eric.ed.gov/?id=EJ1263561.

Bennett, S., Agostinho, S., \& Lockyer, L. (2017). The process of designing for learning: understanding university teachers' design work. Educational Technology Research and Development, 65(1), 125145. https://doi.org/10.1007/s11423-016-9469-y.

Cahapay, M. B. (2020). Rethinking Education in the New Normal Post-COVID-19 Era: A Curriculum Studies Perspective. Aquademia, 4(2). https://doi.org/10.29333/aquademia/8315.

Cahill, M., Hoffman, H., Ingram, E., \& Joo, S. (2020). Supporting School Readiness Through Librarian - Child Interactions in Public Library Storytimes: An Analysis of Assessment Scores and Influential Factors. Early Childhood Education Journal, https://doi.org/10.1007/s10643-020-01133-6.

Chai, C. S., Hwee, J., Koh, L., \& Teo, Y. H. (2018). Enhancing and Modeling Teachers ' Design Beliefs and Efficacy of Technological Pedagogical Content Knowledge for 21st Century Quality Learning. Journal of Education Computing Research, 57(2), 360-384. https://doi.org/10.1177\%2F0735633117752453. 
Engerman, J. A., Carr-Chellman, A. A., \& MacAllan, M. (2019). Understanding learning in video games : A phenomenological approach to unpacking boy cultures in virtual worlds. Education and Information Technologies, 24(2019), 3311-3327. https://doi.org/10.1007/s10639-019-09930-2.

Engerman, J. A., \& Otto, R. F. (2021). The shift to digital : designing for learning from a culturally relevant interactive media perspective. Educational Technology Research and Development, (2021). https://doi.org/10.1007/s11423-020-09889-9.

Fisk, P. (2017). Education 4 . 0 ... the future of learning will be dramatically different, in school and throughout. The Genius Works. http://www.thegeniusworks.com/2017/01/future-education-youngeveryone-taught-together/.

Frey, C. B., \& Osborne, M. A. (2017). The future of employment: How susceptible are jobs to computerisation? Technological Forecasting and Social Change, 114(2017), 254-280. https://doi.org/10.1016/j.techfore.2016.08.019.

Halimah, \& Syaddad, H. N. (2020). Preparing the Preservice Teachers to be the Industrial Revolution Teacher 4.0 Era. Advances in Social Science, Education and Humanities Research, 397(ICLIQE 2019), 1165-1173. https://dx.doi.org/10.2991/assehr.k.200129.144.

Huber, S. G., \& Helm, C. (2020). COVID-19 and schooling : evaluation, assessment and accountability in times of crises - reacting quickly to explore key issues for policy, practice and research with the school barometer. Educational Assessment, Evaluation and Accountability, 32(2), 237-270. https://doi.org/10.1007/s11092-020-09322-y.

Jan, H. (2017). Teacher of 21 st Century: Characteristics and Development Teacher of 21 st Century: Characteristics and Development. Research in Humanities and Social Sciences, 7(9), 50-54. https://core.ac.uk/download/pdf/234675955.pdf.

Julia, C., \& Antoli, J. O. (2018). Impact of implementing a long-term STEM-based active learning course on students ' motivation. International Journal of Technology and Design Education, 29(2), 303-327. https://doi.org/10.1007/s10798-018-9441-8.

Koh, J. H. L. (2018). TPACK design scaffolds for supporting teacher pedagogical change. Educational Technology Research and Development, 67(2019), 577-595. https://doi.org/10.1007/s11423-0189627-5.

Machfiroh, R., Sapriya, \& Komalasari, K. (2020). Indonesian Youth Readiness in Supporting Unlimited Education Society 5.0. Advances in Social Science, Education and Humanities Research, 418(Acec 2019), 529-533. https://dx.doi.org/10.2991/assehr.k.200320.100.

Ministry of Education, Culture, Sport, S. and T. (2019). Information on MEXT's measures against COVID-19. Ministry of Education, Culture, Sport, Science and Technology of Japan. https://www.mext.go.jp/en/mext_00006.html.

Mulyadi, Y. (2019). Vocational Teacher Perception on Industry 4.0 and Society 5.0. Global Conferences Series: Sciences and Technology (GCSST), Volume 2, 2019 The 1st International Conference on Education, Sciences and Technology, 2(2019), 62-68. https://series.gci.or.id/assets/papers/icestech-2019126.pdf.

Mulyanti, B., Purnama, W., \& Pawinanto, R. E. (2020). Distance learning in vocational high schools during the covid-19 pandemic in West Java province, Indonesia. Indonesian Journal of Science and Technology, 5(2), 271-282. https://doi.org/10.17509/ijost.v5i2.24640.

Obana, J. (2020). Could educational technology be a 'holy grail 'amid Covid-19 crisis? Manila Times. https://www.manilatimes.net/2020/03/18/ business/columnists-business/couldeducationaltechnology-be-a-holy-grail-amid-Covid-19-crisis /704202/ .

Onyema, E. M., Sen, S., \& Alsayed, A. O. (2020). Impact of Coronavirus Pandemic on Education. Journal of Education and Practice, 11(1), 108-121. https://genbase.iiep.unesco.org/workspace/applis/epidoc/fichiers/EPIDOC/38698_52821_5658 4_1_PB.pdf.

Pears, K., \& Kim, H. K. (2019). School Readiness in Children in Out-of- - Home Care. Children's Well-Being: Indicators and Research, 22(2019), 105-116. https://doi.org/10.1007/978-3-030-26372-0_8. 
Purnamasari, F., Nanda, H. I., Anugrahani, I. S., Muqorrobin, M. M., \& Juliardi, D. (2019). The Late Preparation Of Ir 4.0 And Society 5.0: Portrays On The Accounting Students' Concerns. South East Asia Journal of Contemporary Business, Economics and Law, 19(5), 212-217. https://seajbel.com/wpcontent/uploads/2019/12/SEAJBEL19_282.pdf.

Rahardjo, D., Sumardjo, Lubis, D. P., \& Harijati, S. (2016). Internet access and usage in improving students' self-directed learning in Indonesia open university. Turkish Online Journal of Distance Education, 17(2), 30-41. https://doi.org/10.17718/tojde.90196.

Rusdin, N. M. (2018). Teachers ' Readiness in Implementing 21 st Century Learning Teachers ' Readiness in Implementing 21 st Century Learning. International Journal of Academic Research in Business and Social Sciences, 8(4), 1271-1284.

Shiroishi, Y., Uchiyama, K., \& Suzuki, N. (2018). Society 5.0: For Human Security and Well-Being. Computer, 51(7), 91-95. https://ieeexplore.ieee.org/abstract/document/8423130.

Shonfeld, M., \& Magen-nagar, N. (2017). The Impact of an Online Collaborative Program on Intrinsic Motivation, Satisfaction and Attitudes. Technology, Knowledge and Learning, 25(2), 297-313. https://doi.org/10.1007/s10758-017-9347-7.

Simaremare, S. A., Hasibuan, N. I., \& Priyadi, M. (2020). Teacher readiness in accommodating the TPACK framework to meet teacher competence the 21st Century Teacher readiness in accommodating the TPACK framework to meet teacher competence the 21st Century. International Conference on Science Education and Technology, 1151(1), 1-7. https://doi.org/10.1088/17426596/1511/1/012041.

Skobelev, \& Borovik. (2017). On The Way From Industry 4.0 to Industry 5.0: From Digital Manufacturing to Digital Society. International Scientitic Journal “Industry 4.0," 2(6), 307-311. https://stumejournals.com/journals/i4/2017/6/307.

Spiteri, M., Nu, S., \& Rundgren, C. (2018). Literature Review on the Factors Affecting Primary Teachers ' Use of Digital Technology. Technology, Knowledge and Learning, 25(1), 115-128. https://doi.org/10.1007/s10758-018-9376-X.

Syarif, M. I., Fauzan, A., \& Munir, S. (2019). Statistics in Elementary School for Society 5.0. Innovation in Islamic Education: Challenges and Readiness in Society 5.0, 2019, 159-168. http://ecampus.iainbatusangkar.ac.id/ojs/index.php/proceedings/article/view/2174.

Tondeur, J., Braak, J. Van, \& Ertmer, P. A. (2016). Understanding the relationship between teachers ' pedagogical beliefs and technology use in education : a systematic review of qualitative evidence. Educational Technology Research and Development, 65(2016), 555-575. http://dx.doi.org/10.1007/s11423-016-9492-z.

Verawardina, U., Asnur, L., Lubis, A. L., Hendriyani, Y., Ramadhani, D., Dewi, I. P., Darni, R., Betri, T. J., Susanti, W., \& Sriwahyuni, T. (2020). Reviewing online learning facing the Covid-19 outbreak. Talent Development and Excellence, 12(SpecialIssue3), 385-392.

Wagiran, Pardjono, Suyanto, W., Sofyan, H., Soenarto, S., \& Yudantoko, A. (2019). Competencies of future vocational teachers: Perspective of in-service teachers and educational experts. Cakrawala Pendidikan, 38(2), 388-400. 